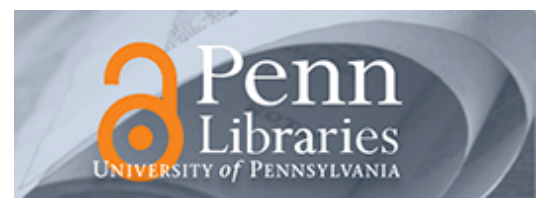

University of Pennsylvania

ScholarlyCommons

$1-1-2006$

\title{
Voice and Biliteracy in Indigenous Language Revitalization: Contentious Educational Practices in Quechua, Guarani, and Maori Contexts
}

Nancy H. Hornberger

University of Pennsylvania, nancyh@gse.upenn.edu

Follow this and additional works at: https://repository.upenn.edu/gse_pubs

Part of the Education Commons

\section{Recommended Citation}

Hornberger, N. H. (2006). Voice and Biliteracy in Indigenous Language Revitalization: Contentious Educational Practices in Quechua, Guarani, and Maori Contexts. Journal of Language, Identity \& Education, 5 (4), 277-292. http://dx.doi.org/10.1207/s15327701jlie0504_2 


\title{
Voice and Biliteracy in Indigenous Language Revitalization: Contentious Educational Practices in Quechua, Guarani, and Maori Contexts
}

\begin{abstract}
This article considers instances of biliterate educational practice in contexts of indigenous language revitalization involving Quechua in the South American Andes, Guarani in Paraguay, and Maori in Aotearoa/NewZealand. In these indigenous contexts of sociohistorical and sociolinguistic oppression, the implementation of multilingual language policies through multilingual education brings with it choices, dilemmas, and even contradictions in educational practice. I consider examples of such contentious educational practices from an ecological perspective, using the continua of biliteracy and the notion of voice as analytical heuristics. I suggest that the biliterate use of indigenous children's own or heritage language as medium of instruction alongside the dominant language mediates the dialogism, meaning-making, access to wider discourses, and taking of an active stance that are dimensions of voice. Indigenous voices thus activated can be a powerful force for both enhancing the children's own learning and promoting the maintenance and revitalization of their languages.
\end{abstract}

\section{Keywords}

Bolivia, Peru, ecology of language, language maintenance, language policy, multilingual education

\section{Disciplines \\ Education}

\section{Comments}


Voice and biliteracy in indigenous language revitalization:

\title{
Contentious educational practices in Quechua, Guarani, and Maori contexts
}

\author{
Nancy H. Hornberger \\ University of Pennsylvania \\ Graduate School of Education \\ 3700 Walnut Street \\ Philadelphia, PA 19104-6216 \\ Tel/Fax: 215-898-7957 or 215-472-8022 \\ nancyh@gse.upenn.edu
}

\author{
Paper submitted for publication in the \\ Journal of Language, Identity, and Education
}

December 2004 


\title{
Voice and biliteracy in indigenous language revitalization:
}

\section{Contentious educational practices in Quechua, Guarani, and Maori contexts}

\begin{abstract}
This paper considers instances of biliterate educational practice in contexts of indigenous language revitalization involving Quechua in the South American Andes, Guarani in Paraguay, and Maori in Aotearoa/New Zealand. In these indigenous contexts of sociohistorical and sociolinguistic oppression, the implementation of multilingual language policies through multilingual education brings with it choices, dilemmas, and even contradictions in educational practice. I consider examples of such contentious educational practices from an ecological perspective, using the continua of biliteracy and the notion of voice as analytical heuristics. I suggest that the biliterate use of indigenous children's own or heritage language as medium of instruction alongside the dominant language mediates the dialogism, meaning-making, access to wider discourses, and taking of an active stance that are dimensions of voice. Indigenous voices thus activated can be a powerful force for both enhancing the children’s own learning and promoting the maintenance and revitalization of their languages.
\end{abstract}

Key words: Bolivia, Peru, ecology of language, language maintenance, language policy, multilingual education

Word count: 7060 


\section{Voice and biliteracy in indigenous language revitalization: Contentious educational practices in Quechua, Guarani, and Maori contexts*}

\section{Introduction}

Twenty years ago, I wrote the following, based on my two-year comparative ethnographic study in two highland Quechua communities of Puno, Peru and their schools, one in the midst of implementing an experimental Quechua-Spanish bilingual program and the other following the traditional Spanish-only curriculum, a study in which I had found greater oral and written pupil participation -- in absolute, linguistic, and sociolinguistic terms -- when Quechua was the medium of instruction:

It is often said that Quechua children, and indigenous children in many parts of the world, for that matter, are naturally shy and reticent, and that that is why they rarely speak in school; therefore we should not interfere with their cultural patterns by encouraging them to speak out more. In light of observations such as those outlined above, however, I think we should ask ourselves whether at least some of that reticence is due to the fact that the school language in many of these cases is a language entirely foreign to the child.

Of course, more may be involved than language. In some parts of the world, children are shy in school even though the home language and the school language are the same. Philips (1983) has shown that, for the case of the native American children at Warm Springs, at least, it is the cultural patterns themselves which are precisely the 
key to the children's participation. Given participation structures which are more congruent with their own cultural patterns, Warm Springs children do participate more in school. Participation structures may also be a factor in the case of Quechua children. Nevertheless, an even more fundamental issue seems to be language. Who, after all, can speak out in a language which they do not know?

For example, I had opportunity to observe one little girl in both classroom and home settings. This little seven-year-old rarely, if ever, spoke in class; yet, at home, she was something of a livewire. She talked non-stop to me (in Quechua), telling me all about the names and ages of her whole family, showing me the decorations on the wall of her home, the blankets woven by her grandmother, borrowing my hat -- all this while she jumped on the bed, did somersaults, cared for her two baby brothers, and so on. (Hornberger 1988: 194, based on Hornberger 1985: 498-499)

Then, as now, it struck me that this little girl, whom I call Basilia, lost her voice at school and found it at home and that use of her own language in familiar surroundings was key in the activation of her voice. In the intervening twenty years, our notions of voice have developed and filled out, largely due to the influential work of Russian Mikhail Bakhtin. Here I consider this opening instance from twenty years ago, along with three other, more recent instances of educational practice in indigenous contexts, all in light of our developing understanding of voice. 
The two grand questions driving me in that study twenty years ago, and in much of my work since then, have been: (1) what educational approaches best serve (indigenous and immigrant) language minority children? and (2) what policies, programs and circumstances encourage or contribute to (indigenous and immigrant) minority language maintenance and revitalization? I have argued through my empirical and theoretical work that multilingual language policies implemented through bilingual education can be a positive factor in answering both those needs, i.e. in enhancing children's learning, and in promoting language maintenance and revitalization (Hornberger 1988, 1998, 2002, 2003).

In the first instance, i.e. the role of mother-tongue-based bilingual education (Alexander 2003) in enhancing language minority children's learning, my argument is supported by my own and others' work as analysed through the continua of biliteracy framework (Hornberger 1989, Hornberger \& Skilton-Sylvester 2000, Hornberger 2003), which in a very fundamental sense is built on the common-sense premise that we learn best based on what we already know. In the second instance, i.e. the role of mother-tongue-based bilingual education in promoting language maintenance and revitalization given a supportive policy and societal context, my argument is further backed up by Fishman's Reversing Language Shift framework (Fishman 1991, 2000), which has as one of its key planks that children must learn to speak the heritage language if it is to survive into the next generation. 
My continuing quest for a more complete understanding of the role of multilingual language education policies in indigenous language revitalization has coincided with a dramatic increase in instances of multilingual language policy around the world, even while (and perhaps because) the English language continues its seemingly inexorable trajectory toward becoming the most global language the world has ever known. Three indigenous contexts of multilingual language policy are the Andes, Paraguay, and Aotearoa/New Zealand. In the Andes, language education policy in Peru of the 1970s opened the way for implementation of internationally-funded experimental bilingual education programs in Quechua and other indigenous communities in the 1980s; and in Bolivia, the National Education Reform of 1994 sought to implant bilingual education nationwide, incorporating all 30 Bolivian indigenous languages, beginning with the three largest -- Quechua, Aymara, and Guarani (Hornberger \& López 1998; López \& Küper 2004). In Paraguay, the demise of a multidecade dictatorship in the early 1990s ushered in a new democratic language education policy which seeks to implant instruction through the medium of Guarani alongside Spanish in all grades and in all schools of the nation, incrementally one year at a time (Choi 2003, 2004; Corvalán 1998; Gynan 2001 a, b). In Aotearoa/ New Zealand, a grassroots movement was born in the 1980s among the Maori to save their language from further decline; these were the pre-school language nests, or kohanga reo, where English-speaking Maori children are immersed in Maori language and culture using a total immersion approach which goes way beyond language to other media, modes, and content. That early initiative has in turn spawned the development of Maori-medium primary, secondary, and most recently tertiary level 
Maori-medium education as well, now overseen by the national Ministry of Education and the Education Review Office (Durie 1999; May 1999, 2002; Spolsky 2003).

In these indigenous contexts of sociohistorical and sociolinguistic oppression, the implementation of multilingual language policies through bi/multilingual education brings with it choices, dilemmas, and even contradictions in educational practice. In Basilia's instance, her class and school had been in the midst of implementing an experimental Quechua-Spanish bilingual education program that was discontinued the following year in her community, under contentious circumstances (Hornberger 1987). In what follows, I consider examples of such contentious educational practices in this and three more recent instances observed in indigenous Quechua, Guarani, and Maori

contexts. ${ }^{\mathrm{i}}$ In doing so, I adopt an ecological perspective, using the continua of biliteracy and Bakhtinian notions of voice as analytical heuristics, in seeking to understand how it is that the use of indigenous languages as medium of instruction in indigenous communities can contribute to both enhancing children's learning and revitalizing the indigenous language.

\section{An ecological perspective on indigenous language revitalization and biliteracy} An ecology of language perspective can be succinctly characterized in terms of three themes salient in both early (Haugen 1972) and more recent (Mühlhaüsler 1996, Phillipson \& Skutnabb-Kangas 1996, Kaplan \& Baldauf 1997, and Ricento 2000, Hornberger 2002) writings. The first theme is that languages, like living species, evolve, grow, change, live, and die in relation to other languages -- the language evolution theme. 
Second, languages interact with their environment (sociopolitical, economic, cultural, educational, historical, demographic, and so on) -the language environment theme. A third theme is the notion that some languages, like some species and environments, may be endangered and that the ecology movement is about not only studying and describing those potential losses, but also counteracting them; this I call the language endangerment theme.

Ecology of language, then, recognizes that planning for any one language in a particular context necessarily entails planning for all languages impinging on that one. The power relations and dynamics among languages and their speakers cannot be ignored. It is precisely because of those unequal relations of power and the increasing recognition that an alarming portion of the world's languages are endangered (Krauss 1992), that language revitalization, and in particular indigenous language revitalization, has arisen as a scholarly and activist focus of concern primarily in the 1990s. Defined as "the attempt to add new linguistic forms or social functions to an embattled minority language with the aim of increasing its uses or users” (King 2001: 23), language revitalization is closely related to earlier sociolinguistic concerns with vitality (Stewart 1968) and revival (Fellman 1974; Edwards 1993), and with more recent notions of renewal (Brandt \& Ayoungman 1989:43) and reversing language shift (Fishman 1991).

Language revitalization goes one step further than language maintenance, in that it implies recuperating and reconstructing something which is at least partially lost, rather than maintaining and strengthening what already exists. Whereas work on language 
maintenance (and shift) has focused as much on immigrant as on indigenous languages (or perhaps more so), language revitalization work carries a particular emphasis on indigenous languages. Likewise, while research on language maintenance and shift has been biased toward documenting cases of shift rather than maintenance (Hyltenstam \& Stroud 1996: 568), documentation on language revitalization emphasizes the positive side of the equation, despite seemingly insurmountable odds against survival of the languages in question. Another difference between maintenance and revitalization work is the relative emphasis placed on conscious and deliberate efforts by speakers of the language to affect language behavior, i.e. on language planning. While language maintenance has long been recognized as a language planning goal (e.g. Nahir 1977, 1984) and language revitalization only more recently so, nevertheless it is also true that maintenance can describe a "natural" language phenomenon that does not require any deliberate planning on the part of its speakers, while revitalization cannot. Finally, whereas language maintenance efforts have often tended to emanate from the top-down (in which someone takes benevolent initiative in “maintaining” someone else’s language), language revitalization efforts tend to originate within the speech community itself (e.g. RLS, Fishman 1991, 2000) as counter-hegemonic social movements (Alexander 2003).

Indeed, King and I have argued that it is crucially important that the speakers of the language be involved in revitalization, since it entails altering not only the traditional language corpus but also how it is traditionally used, both at the micro level in terms of interpersonal discourse patterns and at the macro level of societal distribution; in other words, it is not so much about bringing a language back, as bringing it forward. Who 
better or more qualified to guide that process than the present and future speakers of the language, who must and will be the ones taking it into the future? (Hornberger \& King 1996: 315). This recognition sets the stage for understanding the role of biliteracy and voice in contributing to indigenous children's learning and in turn to indigenous language revitalization.

The continua of biliteracy is an ecological framework for situating educational research, policy, and practice in linguistically and culturally diverse settings around the world. The framework incorporates the language evolution, language environment, and language endangerment themes of the ecology of language. The very notion of bi (or multi)literacy assumes that one language and literacy is developing in relation to one or more other languages and literacies (language evolution); the model situates biliteracy development (whether in the individual, classroom, community, or society) in relation to the contexts, media, and content in and through which it develops (i.e. language environment); and it provides a heuristic for addressing the unequal balance of power across languages and literacies (i.e. for both studying and counteracting language endangerment).

Biliteracy, in this framework, refers to "any and all instances in which communication occurs in two (or more) languages in or around writing" (Hornberger 1990: 213). Specifically, the continua of biliteracy depict the development of biliteracy along first language - second language, receptive-productive, and oral-written language skills continua; through the medium of two (or more) languages and literacies whose linguistic 
structures vary from similar to dissimilar, whose scripts range from convergent to divergent, and to which the developing biliterate individual's exposure varies from simultaneous to successive; in contexts that encompass micro to macro levels and are characterized by varying mixes along the monolingual-bilingual and oral-literate continua; and with content that ranges from majority to minority perspectives and experiences, literary to vernacular styles and genres, and decontextualized to contextualized language texts (Hornberger 1989; Hornberger \& Skilton-Sylvester 2000) (see Figure 1).

Figure 1 about here

These 12 continua can be conceptualized as 4 nested sets of 3 intersecting continua each. The nested sets represent development, media, contexts, and content of biliteracy respectively, each set made up of a cluster of its three intersecting continua. Not only is the three-dimensionality of any one set of three intersecting continua representative of the interrelatedness of those three constituent continua, but the interrelationships also extend across the four sets of continua; hence the nesting of the three-dimensional spaces.

The notion of continuum conveys that all points on a particular continuum are interrelated, and the intersecting and nested relationships among the continua convey that all points across the continua are also interrelated. The model suggests that the more their learning contexts and contexts of use allow learners and users to draw from across the whole of each and every continuum, the greater are the chances for their full biliterate development and expression 
(Hornberger 1989: 289). Implicit in that suggestion is a recognition that there has usually not been attention to all points and that movement along the continua and across the intersections may well be contested. In educational policy and practice regarding biliteracy, there tends to be an implicit privileging of one end of the continua over the other such that one end of each continuum is associated with more power than the other (e.g. written development over oral development); there is a need to contest the power weighting in any given instance by paying attention to, granting agency to, and making space for actors and practices at the less powerful ends of the continua (Hornberger \& Skilton-Sylvester 2000: 99).

In order to understand any particular instance of biliteracy, be it at the level of individual actor, interaction, event, practice, activity, program, site, situation, society, or world, we need to take account of all dimensions represented by the continua. At the same time, the advantage of the model is that it allows us to focus for analytical purposes on one or selected continua and their dimensions without ignoring the importance of the others; that is precisely what we will do below, in relation to Bakhtinian notions of voice.

\section{Voice and contentious biliterate educational practices}

Voice is what seven-year-old Basilia in my opening quote joyfully expresses through the medium of her own language in her own home, surrounded by familiar people and objects. She vividly exemplifies the individual in active dialogue with her environment, i.e. the dialogism which is a prominent theme of Bakhtin's work and "begins from the premise that sentient beings -- alone and in groups -- are always in a state of active 
existence; they are always in a state of being 'addressed' and in the process of 'answering"' (Holland \& Lave 2001: 9-10). Holquist put it this way:

Existence is addressed to me as a riot of inchoate potential messages, which at this level of abstraction may be said to come to individual persons much as stimuli from the natural environment come to individual organisms. Some of the potential messages come to me in the form of primitive physiological stimuli, some in the form of natural language, and some in social codes or ideologies. So long as I am in existence, I am in a particular place, and must respond to all of these stimuli either by ignoring them or in a response that takes the form of making sense, of producing -for it is a form of work -- meaning out of such utterances (Holquist 1990:47, cited in Holland \& Lave 2001: 10).

It would appear that seven-year-old Basilia was perhaps ignoring the stimuli at school while responding actively to those at home; the voice that was lost at school was exuberantly found at home.

Voice, in Bakhtin's concept, is the speaking consciousness, articulated as social practice, in dialogue with others and in situated contexts. These notions have increasingly found their way into a reconceptualization of voice in language and education, in which learners can be seen as engaging in dialogical struggles for speaking consciousness (Norton 1997; Solá \& Bennett 1985; Walsh 1991).

Beginning from dialogism as the first theme in Bakhtin's concept of voice, Holland and Lave (2001) highlight three additional dialogical themes in Bakhtin’s writings. Self- 
authoring is the second theme; in the making of meaning, we author the world and ourselves in it, and in doing so, draw on languages, dialects, cultural genres, and the words of others to which we have been exposed, as the media through which our senses of self and group are developed. A third theme is that "all dialogic engagements of self... are struggles across and about differences between self and others," animated by "discourses widely circulating locally and beyond"; while a fourth highlights the active stances persons take toward others and the dialects, languages, genres, and other cultural forms they produce (Holland \& Lave 2001: 10-14).

Holland and Lave elucidate these themes in their edited volume, History in Person, where they posit the "mutually constitutive nature of language and complex social, political, and economic struggles and the historically fashioned identitites-in-practice and subjectivities that they produce" and suggest an analytic approach that starts with "local struggles" -- that is, struggles in particular times and places (2001: 109). They tell us that enduring struggles are crucibles for the forging of human subjects' identities through contentious local practice. Borrowing from their approach, I am here interested in the forging of indigenous children's voices in the crucible of indigenous people's enduring struggles, through contentious local practice in schools.

I examine instances of contentious biliterate educational practice in contexts of indigenous language revitalization, using the continua of biliteracy and the four Bakhtinian themes as analytical heuristics to understand the ways in which the use of indigenous languages as medium of instruction in indigenous language communities may 
contribute to both enhancing children's learning and revitalizing the indigenous language through the activation of voice. Specifically, I suggest that activation of indigenous children's voices enables them to negotiate along and across the various continua making up the development, contexts, content, and media of biliteracy.

\section{Biliteracy development and dialogic voices: Quechua in Peru in the 1980s}

We already saw above how little Basilia's active engagement in the dialogical process of being addressed or answering/responding contributes to her lively oral interaction in Quechua at home, while her more passive engagement at school, where Spanish is dominant, leaves her silent. In the Bakhtinian sense, her voice is activated at home, but silenced at school. In terms of the consequences of this loss of voice for her biliteracy development, until she can use her first language (L1) in productive and receptive, written and oral modes at school, it will be difficult for her to develop her second language ( L2) to its fullest.

\section{Biliteracy content, cultural genres, and self-authoring: Quechua in Bolivia in the 1990s}

The second instance of contentious biliterate educational practice comes from a visit to a rural school in the department of Cochabamba in Bolivia.

After about an hour's drive from Cochabamba in the luxury of a project jeep, chauffeur Elio and I arrive at Kayarani school at about 10:30 am and are greeted in the schoolyard by several dozen children rushing over to the car to shake our hands. We approach the low adobe building where the teachers live during the 
school week and are met at the door by head teacher Berta and Angélica who is currently substituting for the $\mathrm{K}-1^{\text {st }}$ grade teacher on maternity leave. A third teacher is absent today. Berta, a native of Tarija, has been teaching here at Kayarani for three years, implementing bilingual education under the 1994 National Education Reform. She began with her class from the start of their schooling; they are now in $2^{\text {nd }}-3^{\text {rd }}$ grade.

A new school building was inaugurated last year and the rooms are nice, with tables and chairs that can be set up for group work. Berta's classroom, the only one I observed, is decorated with a lot of posters she's made in Quechua, including models of a story, a poem, a song, a recipe, a letter; as well as both the Quechua and Spanish alphabets (which she has the students recite for me later). Also on the wall is the class newspaper, Llaqta Qapariy (Voice of the People), featuring an article in Quechua written by student Calestino about farmers' wanting better prices for their potatoes.

A key provision of the Bolivian Education Reform is the establishment of a library in every primary classroom of the nation, each one stocked with a collection of 80 books provided by the Ministry of Education through the auspices of UNESCO. Included are 6 Big Books in Spanish, 3 of them based on oral traditions in Quechua, Aymara, and Guarani, respectively: El Zorro, el Puma y los Otros 'The Fox, the Puma, and the Others'; La Oveja y el Zorro 'The Sheep and the Fox'; La Chiva Desobediente 'The Disobedient Goat'. The Big Books are 
approximately 18 " x 24", with large print text and colorful illustrations, such that the pictures can be seen by the whole class if the teacher holds the book up in front of the class in a reading circle. Berta's classroom, too, has a library corner housing a small collection including a couple of Big Books, and she calls on a child to come to the front of the class to read one of the Big Books aloud to his classmates. Later, after the class leaves for recess, a couple of the children notice my interest in the Big Books and come over to gleefully hold the books up for a photo (14 August 2000, Kayarani).

The instance of contentious biliterate educational practice I am drawing attention to here is the use of indigenous oral tradition within the Spanish language literacy materials of the Reform -- an instance of minority, vernacular, contextualized content in the second language. This practice might be doubly contentious with, on the one hand, a purist indigenous perspective rejecting the presentation of indigenous content in a nonindigenous language, and on the other, a hispanicist-assimilationist perspective rejecting the inclusion of indigenous content in Spanish language texts. Yet from the point of view of biliteracy development, this practice constitutes a strong support for the learner or user of the texts. Given that, in the Bakhtinian sense, an individual develops a sense of self through incorporating the languages, dialects, genres, and words of others to which she has been exposed, this biliterate practice offers a familiar voice for indigenous children to incorporate in their own voices.

\section{Biliteracy context, dialogic engagement, and circulating discourses:}




\section{Guarani in Paraguay in the 1990s}

The third instance of contentious biliterate educational practice emerged in a meeting of the curricular team of the Ministry of Education and Culture of Paraguay.

I spent one morning with members of the Curriculum team at the Ministry of Education and their consultants Delicia Villagra and Nelson Aguilera, brainstorming the design for Guarani and Spanish language and literature curriculum for the secondary level. Paraguay's Bilingual Education Reform introduced Guarani as language of instruction alongside Spanish, beginning in $1^{\text {st }}$ grade in 1993 and progressively adding one grade each year; 2001 would complete the primary cycle (grades 1-9) and Guarani instruction at the secondary level was to be introduced for the first time in February 2002.

The complexity of issues needing to be addressed are staggering; not only is this the first time in South America (to our knowledge) that an indigenous language with relatively little tradition of technical, scientific, or literary use will be introduced into the secondary curriculum, but there are also unresolved issues lingering from the past nine years of primary bilingual education in Paraguay, including a lack of bilingual teacher preparation, inadequate language teaching methodology, lack of consensus on which Guarani to use in the schools, and negative attitudes towards the use of Guarani in the schools from some parents and communities. Not to mention the exponentially escalating demand for and market in English language education in the schools. None of these challenges is unique to Guarani; in fact these "problems in the socio-educational legitimization 
of languages / varieties" (Fishman 1982:4-6) regularly attend the introduction of vernacular languages into education worldwide, historically and in the present. Nevertheless, they are very real challenges which the Curriculum Department must address in order to advance the use of Guarani in secondary education.

For the time being, as a pragmatic measure, the team has opted to require the teaching of Guarani literature through the medium of Guarani, while leaving the medium of instruction for other curricular areas at the secondary level --such as math, science, and social studies-- up to the decision of each school. As a strategy toward the promotion of Guarani, the team plans to orient the Guarani language and literature curriculum strongly toward production of texts in a variety of genres, the goal being to create a generation of confident and prolific Guarani writers who will in turn develop and intellectualize the language, so that it can subsequently be introduced into all areas of the secondary curriculum (4 October 2001, Asunción).

The instance of contentious biliterate educational practice I am drawing attention to here is the ecological approach to use of Spanish as medium of instruction alongside Guarani, even in the midst of a reform calling for the strengthening of Guarani. In terms of the continua of biliterate context, this is a case of ceding some ground to the more powerful monolingual, literate, macro contexts, while simultaneously attempting to gain ground at the multilingual, oral, micro contexts. Given that, in Bakhtinian terms, dialogic selves are animated by discourses circulating locally and beyond, such a practice attempts to 
offer a chance for Paraguayan students to incorporate both local Guarani and wider Spanish discourses in their own, thereby contributing to their academic and biliteracy development.

\section{Biliteracy media and the active stance:}

\section{Maori in Aotearoa/New Zealand beginning in the 1980s}

The fourth instance of contentious biliterate educational practice is seen in a Maori immersion primary school in Aotearoa/New Zealand.

We three --my colleague Stephen May of the University of Waikato, his colleague Karaitiana Tamatea, parent and former whanau (extended family) leader at the school, and I-- enter the kura kaupapa Maori (Maori immersion school) following the traditional protocol (powhiri), which means that the assistant principal (in the principal's absence) greets us with a chant while we are still outside the premises, and then we slowly enter, exchanging chants with her as we do. After a continuation of this protocol inside one of the classrooms where all 80 children (grades 1-6) are gathered for our visit, we are invited to a different room for refreshments. Because of the strict prohibition on the use of English anywhere on the school premises at all times, this is the only room where I, a non-Maori speaker, can have a conversation with teachers, staff, and leadership of the school.

I am introduced to the current whanau leader. Here, as is the case for the 58 other kura kaupapa schools in Aotearoa/New Zealand, the whanau has been indispensable in the establishment and existence of the kura kaupapa. The school 
exists in the first place only by initiative of the whanau; and only after two years of running the school themselves may they appeal for government recognition and support. This school was founded in 1995 and gained recognition and its own school building and grounds several years ago.

The whanau leader asks me "What do you think of bilingual education?" As I formulate my answer and engage in further dialogue with him, it suddenly dawns on me that for him, bilingual education and Maori immersion are opposites, while for me they are located on a continuum. Maori-only ideology is of such integral and foundational importance to Maori immersion that the use of two languages (English and Maori) suggested by the term bilingual is antithetical to those dedicated to Maori revitalization (28 June 2002, Hamilton).

The instance of contentious biliterate educational practice I am drawing attention to here is the absolute prohibition on English language use on the kura kaupapa grounds, an instance, in terms of the continua of biliteracy, of successive exposure to the media of biliteracy, strictly enforced. The prohibition is controversial in a nation where English is socially and educationally dominant and highly desirable for academic and social advancement; and all the more controversial considering that the Maori children attending the school arrive as English speakers. Nevertheless, Maori immersion education, with its strict Maori-only enforcement, has been highly successful in bringing Maori language back from the brink of disappearing. Given that, in Bakhtinian terms, speakers not only use the words of others, but take active stances with respect to those 
words, this contentious practice, I suggest, represents an active stance taken by the kura kaupapa to maximize activation of indigenous student voice and heritage indigenous language revitalization.

A famous teacher of Maori children, Sylvia Ashton-Warner, understood the importance of indigenous children's voice, even though, ironically, she taught through the medium of English. In the 1930s, she developed and used an approach she called organic reading and organic writing, described in her book Teacher. She writes: "first words must mean something to a child" and again, "first words must have intense meaning for a child. They must be part of his being" (1963:33). She continues, commenting on the writings of her Maori students:

These books they write are the most dramatic and pathetic and colourful things I've ever seen on pages. But they are private and they are confidences and we don't criticize their content. Whether we read that he hates school or that my house is to be burned down or about the brawl in the pa (Maori village) last night the issue is the same: it is always not what is said but the freedom to say (1963:52-54)

By extraordinary measures, she was able to activate her indigenous students' voice, even without primary use of their language. How much more often is it the case that denial of students' language also strips them of their voice?

\section{Conclusion}

Haugen argued that language itself is not a problem, but language used as a basis for discrimination is (1973). McCarty, considering the struggle for self-determination among 
Native people in the United States, concludes that while "language can be an instrument of cultural and linguistic oppression, [it] can also be a vehicle for advancing human rights and minority community empowerment" (2003: 160). It is, I suggest, the activation of indigenous voice that tilts use of the indigenous language away from discrimination and oppression and toward emancipation, self-determination, and empowerment.

Giroux tells us that 'Language represents a central force in the struggle for voice ... language is able to shape the way various individuals and groups encode and thereby engage the world' (Giroux 1986: 59, cited in Ruiz 1997: 320). This is as true for immigrant as for indigenous language minority students. Maxine Hong Kingston, who wrote the forward for the republication of Teacher in 1963, writes in her novel Woman Warrior about silencing and voice for Chinese children in school in America:

When I went to kindergarten and had to speak English for the first time, I became silent....My silence was thickest -- total-- during the three years that I covered my school paintings with black paint..... During the first silent year I spoke to no one at school, did not ask before going to the lavatory, and flunked kindergarten. ... I enjoyed the silence. At first it did not occur to me I was supposed to talk or to pass kindergarten. I talked at home and to one or two of the Chinese kids in class. I made motions and even made some jokes..... I liked the Negro students (Black Ghosts) best because they laughed the loudest and talked to me as if I were a daring talker too....

It was when I found out I had to talk that school became a misery, the silence became a misery. I did not speak and felt bad each time that I did not speak. ... The other 
Chinese girls did not talk either, so I knew the silence had to do with being a Chinese girl.

After American school, we picked up our cigar boxes, in which we had arranged books, brushes, and an inkbox neatly, and went to Chinese school, from 5:00 to 7:30 pm. There we chanted together, voices rising and falling, loud and soft, some boys shouting, everybody reading together, reciting together and not alone with one voice.... Not all of the children who were silent at American school found voice at Chinese school. (Kingston 1975: 165-168)

True enough, not all indigenous or language minority children find voice through use of their own language in school. "It's much more than language," ethnographer Freeman is told as she sets out to document Washington D.C. Oyster School's bilingual language plan and ends up writing about their identity plan (Freeman 1998). Ruiz, too, has warned us that:

As much as language and voice are related, it is also important to distinguish between them. I have become convinced of the need for this distinction through a consideration of instances of language planning in which the 'inclusion' of the language of a group has coincided with the exclusion of their voice... Language is general, abstract, subject to a somewhat arbitrary normalization; voice is particular and concrete. Language has a life of its own -- it exists even when it is suppressed; when voice is suppressed, it is not heard -- it does not exist. To deny people their language, as in the colonial situations described by Fanon (1967) and Macedo (1983), 
is, to be sure, to deny them voice; but, to allow them "their" language ... is not necessarily to allow them voice. (Ruiz 1997: 320-321)

Perhaps it is not necessarily so, but what I suggest here is that, though it may be that not all indigenous children find voice through use of their language, many of them do; and when they do, it is perhaps because of the ways that the biliterate use of their own or heritage language as medium of instruction alongside the dominant language mediates the dialogism, meaning-making, access to wider discourses, and taking of an active stance that are dimensions of voice. Indigenous voices thus activated can be a powerful force for both enhancing the children's own learning and promoting the maintenance and revitalization of their languages. 


\section{References}

Alexander, N. (2003). Language education policy, national and sub-national identities in south africa (Reference study: Guide for the development of language education policies in Europe - From linguistic diversity to plurilingual education). Strasbourg: Council of Europe: Language Policy Division, DG IV - Directorate of School, Out-of-School and Higher Education.

Ashton-Warner, S. (1963). Teacher. New York: Simon and Schuster.

Brandt, E. A., \& Ayoungman, V. (1989). Language renewal and language maintenance: A practical guide. Canadian Journal of Native Education, 16(2), 42-77.

Choi, J. K. (2003). Language attitudes and the future of bilingualism: The case of paraguay. International Journal of Bilingual Education and Bilingualism, 6(2), 81-94.

Choi, J. K. (2004). La planificación lingüística y la revivificación del guaraní en el paraguay: Comparación, evaluación e implicación. Language Problems and Language Planning, 28(3), 241-259.

Corvalán, G. (1998). La educación escolar bilingüe del paraguay: Avances y desafíos. Revista Paraguaya de Sociología, 35(103), 101-118.

Durie, A. (1999). Emancipatory maori education: Speaking from the heart. In S. May (Ed.), Indigenous community-based education (pp. 67-78). Clevedon, UK: Multilingual Matters.

Edwards, J. (1993). Language revival: Specifics and generalities. Studies in Second Language Acquisition, 15, 107-113.

Fellman, J. (1974). The role of Eliezer Ben Yehuda in the revival of the Hebrew language: An assessment. In J. Fishman (Ed.), Advances in Language Planning (pp. 427-455). The Hague: Mouton.

Fishman, J. A. (1982). Sociolinguistic foundations of bilingual education. The Bilingual review/ La revista bilingüe, 9(1), 1-35.

Fishman, J. A. (1991). Reversing Language Shift: Theoretical and Empirical Foundations of Assistance to Threatened Languages. Clevedon, UK: Multilingual Matters.

Fishman, J. A. (Ed.). (2000). Can Threatened Languages be Saved? "Reversing Language Shift" Revisited. Clevedon, UK: Multilingual Matters.

Freeman, R. D. (1998). Bilingual education and social change. Clevedon, UK: Multilingual Matters. 
Gynan, S. N. (2001a). Language planning and policy in paraguay. Current Issues in Language Planning, 2(1), 53-118.

Gynan, S. N. (2001b). Paraguayan language policy and the future of guaraní. Southwest Journal of Linguistics, 20(1), 151-165.

Haugen, E. (1972). The Ecology of Language. Stanford, CA: Stanford University Press.

Haugen, E. (1973). The curse of Babel. In M. Bloomfield \& E. Haugen (Eds.), Language as a Human Problem (pp. 33-43). New York: W. W. Norton \& Co.

Holland, D., \& Lave, J. (Eds.). (2001). History in Person: Enduring Struggles, Contentious Practice, Intimate Identities. Santa Fe, New Mexico: School of American Research Press.

Holquist, M. (1990). Dialogism: Bakhtin and His World. London: Routledge.

Hornberger, N. H. (1985). Bilingual Education and Quechua Language Maintenance in Highland Puno, Peru. Unpublished Ph.D. Dissertation, University of WisconsinMadison.

Hornberger, N. H. (1987). Bilingual education success, but policy failure. Language in Society, 16(2), 205-226.

Hornberger, N. H. (1988). Bilingual Education and Language Maintenance: A Southern Peruvian Quechua Case. Berlin: Mouton.

Hornberger, N. H. (1989). Continua of biliteracy. Review of Educational Research, 59(3), 271-296.

Hornberger, N. H. (1990). Creating successful learning contexts for bilingual literacy. Teachers College Record, 92(2), 212-229.

Hornberger, N. H. (1998). Language policy, language education, language rights: Indigenous, immigrant, and international perspectives. Language in Society, 27(4), 439-458.

Hornberger, N. H. (2002). Multilingual language policies and the continua of biliteracy: An ecological approach. Language Policy, 1(1), 27-51.

Hornberger, N. H. (Ed.). (2003). Continua of Biliteracy: An Ecological Framework for Educational Policy, Research and Practice in Multilingual Settings. Clevedon, UK: Multilingual Matters.

Hornberger, N. H., \& King, K. A. (1996). Bringing the language forward: School-based initiatives for Quechua language revitalization in Ecuador and Bolivia. In N. H. 
Hornberger (Ed.), Indigenous Literacies in the Americas: Language Planning from the Bottom up (pp. 299-319). Berlin: Mouton.

Hornberger, N. H., \& López, L. E. (1998). Policy, possibility and paradox: Indigenous multilingualism and education in Peru and Bolivia. In J. Cenoz \& F. Genesee (Eds.), Beyond Bilingualism: Multilingualism and Multilingual Education (pp. 206-242). Clevedon, England: Multilingual Matters.

Hornberger, N. H., \& Skilton-Sylvester, E. (2000). Revisiting the continua of biliteracy: International and critical perspectives. Language and Education: An International Journal, 14(2), 96-122.

Hyltenstam, K., \& Stroud, C. (1996). Language maintenance. In H. Goeble \& P. Nelde \& A. Stary \& W. Wölck (Eds.), Contact Linguistics (pp. 567-578). Berlin: Walter de Gruyter.

Kaplan, R. B., \& Baldauf, R. B. (1997). Language Planning From Practice to Theory. Clevedon, UK: Multilingual Matters.

King, K. A. (2001). Language Revitalization Processes and Prospects: Quichua in the Ecuadorian Andes (Vol. 24 BEB). Clevedon, UK: Multilingual Matters.

Kingston, M. H. (1975). The Woman Warrior: Memoirs of a Girlhood Among Ghosts. New York, NY: Vintage International.

Krauss, M. (1992). The world's languages in crisis. Language, 68, 4-10.

López, L. E., \& Küper, W. (2004). La educación intercultural bilingüe en América Latina: Balance y perspectivas (2nd ed.). La Paz-Cochabamba: Cooperación Técnica Alemana (GTZ)-PINSEIB-PROEIBAndes.

May, S. (1999). Language and education rights for indigenous peoples. In S. May (Ed.), Indigenous community-based education (pp. 42-66). Clevedon, UK: Multilingual Matters.

May, S. (2002). Accommodating multiculturalism and biculturalism in Aotearoa/New Zealand: Implications for language education. Unpublished manuscript.

McCarty, T. L. (2003). Revitalizing indigenous languages in homogenizing times. Comparative Education, 39(2), 147-163.

Mühlhaüsler, P. (1996). Linguistic Ecology : Language Change and Linguistic Imperialism in the Pacific Region. London: Routledge.

Nahir, M. (1977). The five aspects of language planning: A classification. Language Problems and Language Planning, 1(2), 107-122. 
Nahir, M. (1984). Language planning goals: A classification. Language Problems and Language Planning, 8(3), 294-327.

Norton, B. (1997). Critical discourse research. In N. H. Hornberger \& D. Corson (Eds.), Research methods in language and education (pp. 207-216). Dordrecht: Kluwer Academic Publishers.

Phillipson, R., \& Skutnabb-Kangas, T. (1996). English only worldwide or language ecology? TESOL Quarterly, 30(3), 429-452.

Ricento, T. (2000). Historical and theoretical perspectives in language policy and planning. Journal of Sociolinguistics, 4(2), 196-213.

Ruiz, R. (1997). The empowerment of language-minority students. In A. Darder \& R. Torres \& H. Gutierrez (Eds.), Latinos and Education: A Critical Reader (pp. 319328). New York: Routledge.

Solá, M. \& Bennett, A. (1985). The struggle for voice: Narrative, literacy and consciousness in an East Harlem school. Journal of Education 167(1), 88-110.

Spolsky, B. (2003). Reassessing maori regeneration. Language in Society, 32(4), 553578.

Stewart, W. (1968). A sociolinguistic typology for describing national multilingualism. In J. Fishman (Ed.), Readings in the Sociology of Language (pp. 531-545). The Hague: Mouton.

Walsh, C. E. (1991). Pedagogy and the struggle for voice: Issues of language, power, and schooling for puerto ricans. New York: Bergin \& Garvey. 


\section{Power relations in the continua of biliteracy}

traditionally less powerful <-------------> traditionally more powerful

\section{Contexts of biliteracy}

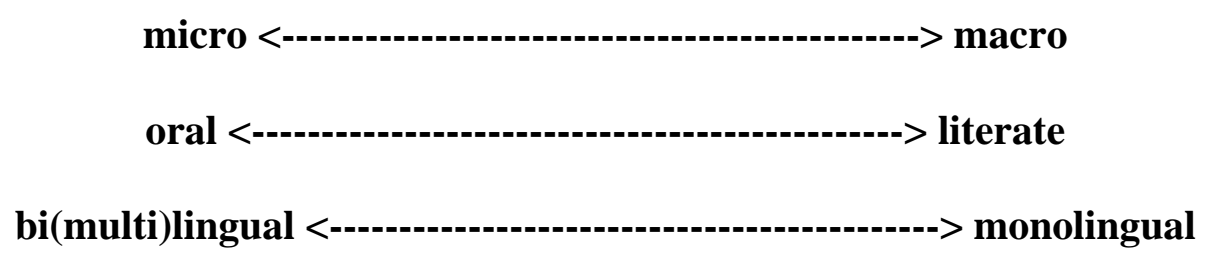

$\underline{\text { Development of biliteracy }}$

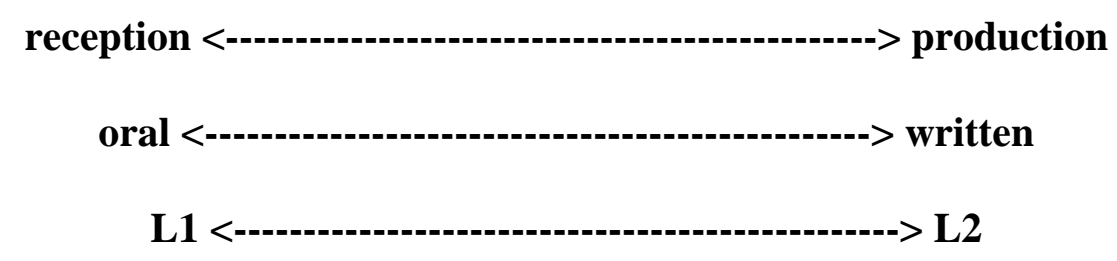

Content of biliteracy

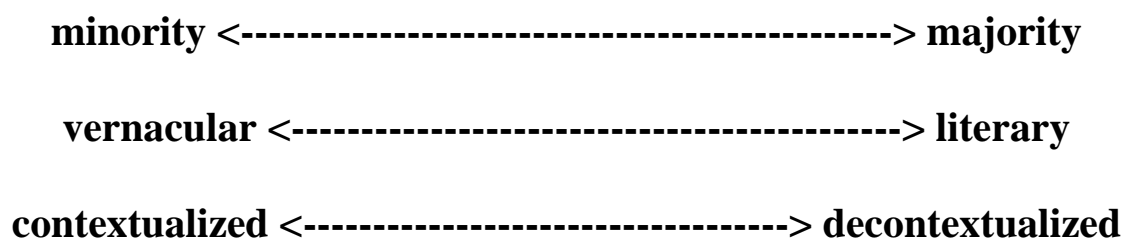

Media of biliteracy

simultaneous exposure <---------------------------> successive exposure

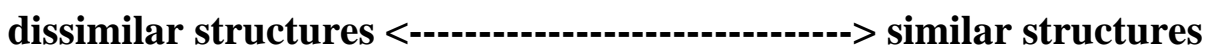
divergent scripts <-------------------------------> convergent scripts

FIGURE 1 
${ }^{*}$ Earlier versions of this paper were presented at the Georgetown University Round Table on Languages and Linguistics in Washington DC, 17 February 2003, at the Fourth International Symposium on Bilingualism in Arizona, 1 May 2003, at the IX International Conference on Minority Languages in Kiruna, Sweden, 6-7 June 2003 and at the International Conference on Language, Education and Diversity, held at the University of Waikato, Hamilton, Aotearoa/New Zealand, 26-29 November 2003. My heartfelt thanks to my colleagues Professor Kendall King of Georgetown University, Professor Terrence Wiley of Arizona State University, Professor Birger Winsa of Stockholm University, and Professor Stephen A. May of Waikato University, respectively, for inviting me to reflect on and talk about these matters in such inspiring venues.

${ }^{1}$ This paper draws on my recent opportunities to revisit the Andean Quechua context and to make first personal acquaintance with the Paraguayan Guarani context and the Aotearoa/New Zealand Maori context. My profound gratitude goes to the Fulbright Senior Specialists Program, which provided grants for my visits to Paraguay (October 2001) and Aotearoa/New Zealand (July 2002). 